\title{
Determinants of Output Market Participation by Smallholder Farmers in Upper Guruve District, Zimbabwe
}

\author{
Benjamine Hanyani-Mlambo $^{1} \quad$ Shawn Chipise $^{1} \quad$ Sheunesu Mpepereki $^{1} \quad$ Paul Gwenzi $^{2}$ \\ 1.University of Zimbabwe (ZIMBABWE) \\ 2.University of Pretoria (SOUTH AFRICA)
}

\begin{abstract}
Market participation by smallholder farmers in Sub-Saharan Africa is characteristically low, with most of these farmers having limited access to both input and output markets. This paper investigates the factors associated with output market participation by smallholder farmers in Upper Guruve District, Zimbabwe. A multi-stage sampling technique was used to select 200 households for the survey, with the collected primary data analyzed using STATA version 15 through a Multinomial Logistic regression model. The key determinants to output market participation included gender, age and experience, area cropped to soyabean, input and output market prices, profitability and access to market and extension support services. The study demonstrates the need for market information dissemination so as to promote and increase soyabean productivity. Government intervention should also focus on providing an enabling environment for improved private sector involvement and gender empowerment since women are currently marginalized in soyabean production and market participation. This paper is critical for guiding policy-making and development of strategies to increase soya production for the benefit of both farmers and the economy in general.
\end{abstract}

Keywords: Soyabean, Output Market Participation, Smallholder Farmers, Zimbabwe

DOI: $10.7176 / \mathrm{JESD} / 12-2-02$

Publication date: January $31^{\text {st }} 2021$

\section{Introduction}

The national production of soyabean in Zimbabwe has declined from an all-time high of about 170,000 metric tonnes in 2001/2 to less than 60,000 metric tonnes in the 2018/19 cropping season. This production level falls far short of the annual requirement of 250,000 MT in an economy boasting almost 500,000 MT of oilseed crushing capacity. Recently the government introduced the Command soyabean initiative so as to boost the production of the crop and also changed the market producer price from USD 610 per MT to USD 780 per MT as a strategy of promoting localized soyabean production and ensuring self sufficiency within the soyabean sector (Chikwati and Siam, 2018).

In the 1920's soyabean (Glycine max) was a legume, which was firstly grown in Zimbabwe as a fodder crop (Membrahtu, 1986; Whingwiri, 1992). Soyabean has multiplicity use. It can be used for medicinal purposes, for human consumption, making feed for livestock and aquaculture, as a source for bio-energy, processing of oil, as a cash crop and increasing the fertility of the soil through biological nitrogen fixation (Smith and Huyser, 1987; Adedoyin, et. al., 1998; Myaka et. al., 20050. As such, soyabean is a high value crop.

Many households and farmers in Upper Guruve District in Zimbabwe bank on soyabean to have a balanced diet since there exists high costs on alternative protein rich crops. According to Duranti and Gius (1997) soyabean grain has a high protein content of about $40 \%$ as compared to other legumes which contain almost half this. Soyabean is crucial in sampled smallholder farmer diets due to high poverty levels in Guruve District. The smallholder farmers' ability to participate in output markets depends on, inter alia, the net income benefits resulting from production of soyabean. Rural smallholder farmers can increase incomes and shun poverty by participating in the market (IFAD, 2003). Several research studies in developing countries show that there is low market participation by smallholder farmers (Barrett, 2008). Smallholder farmers in Southern Africa also find it challenging to participate in the modern economy, with most of these farmers having limited access to input and output markets (Wolfgang et. al., 2016).

In many African countries an increase in market participation by rural smallholder farmers is dynamically connected to economic development and a reduction in poverty (Jagwe et al., 2010; Zanella et al.,2012). Smallholder farmers have many different market channels for marketing their harvest. According to USAID (2010) the channels for marketing can be formal or informal and provides different prices and sales services. Hence, it determines the choice of farmers on the channel to use to market their yield. Many farmers in rural areas have deficiency to dependable market information and information on likely exchange partners (Jagwe et al.,2010). Due to high transactional costs the majority of smallholder farmers in isolated areas source traditional markets such as hawkers and open markets (Louw et al., 2008).

This paper sets to establish factors affecting output market participation of soyabean among smallholder farmers in Zimbabwe. The majority of previous studies on soyabean centered on biophysical aspects of soyabean production. Thus, this study results seeks to contribute to the existing body of knowledge on market participation 
of soyabean which is locally scanty. The study results and insights provided by this study is vital for understanding the marketing of soyabean by smallholder farmers whose improved participation in both input and output markets may lead to higher incomes, soil fertility improvements and poverty reduction.

The findings of the research are anticipated to inform agricultural policymakers on suitable policies to increase soyabean market participation by smallholder farmers, expand soyabean production output and increase productivity levels, and either generate or contribute towards the re-crafting of more appropriate policies. This will in turn progress soyabean production, facilitating the introduction of other programs other than Command Soyabean, as well as encourage producers to engage soyabean input and output markets.

\section{Methodology}

\subsection{Area under study}

The study was conducted in Upper Guruve District, one of the north most parts of Zimbabwe. Guruve District has two sections viz: the upper and lower boundaries hence the distinction. Guruve District is bordered by Mbire District to the north, Centenary District to the east, Mazowe district to the south and Makonde District to the west. See Figure 1. Guruve District has a total population of 200,833 inhabitants (ZIMSTATS, 2013), and covers land area of 2,994 $\mathrm{km}^{2}$. The district is divided into 25 administrative wards, each with $20-60$ villages. According to the information from officers within the Department of Agricultural, Technical and Extension Services (AGRITEX) in the district, the target enumeration areas i.e. Ward 5 consisted of 1,814 soyabean farming households, while Ward 4 had 1,446 soyabean farming households.
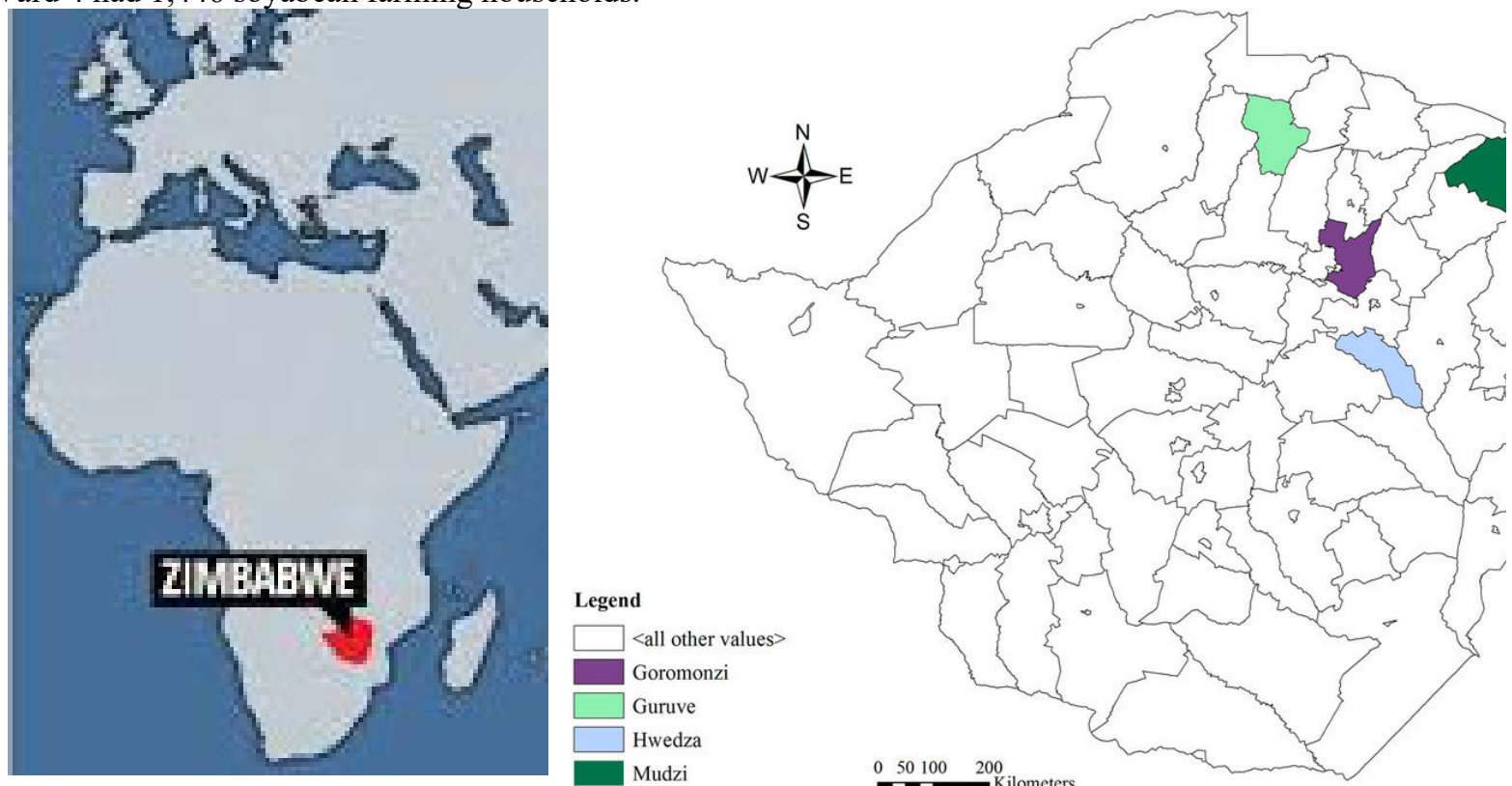

Figure 1: Map of Zimbabwe relative to Africa, and showing Guruve District.

The study area lies in agro-ecological regions III and IV. It receives an annual rainfall of $650 \mathrm{~mm}$ while the annual average temperature is $26.5^{\circ} \mathrm{C}$. The coordinates are $16^{\circ} 20^{\prime} 0^{\prime \prime} \mathrm{S}$ and $30^{\circ} 35^{\prime} 0^{\prime \prime} \mathrm{E}$, with an altitude of $410-450$ meters above sea level. The crops suitable for cultivation in the district include soyabeans, maize (Zea mays) and common beans (Pharsalus vulgaris L). Crop farming is the main source of livelihood, with maize being mostly grown as cereal crop. On the other hand, soyabeans and common beans dominate as the main legume cash crops. The largest agricultural marketing centre is Guruve Centre. The district has poor market conditions largely due to poor infrastructure. A network of gravel/dirty roads act as the main link between rural agricultural production areas, neighbouring rural areas and urban markets. This network of dirty roads also link rural agricultural production areas to the main tarred/surfaced road, which is approximately $151 \mathrm{~km}$ from the main legume output market in the Harare.

\subsection{Data sampling}

A multi-stage sampling technique was adopted for sampling. At the onset, Upper Guruve District was purposively selected for being one of the highest soyabean producing districts in Zimbabwe and by virtue of it being one of the districts with the least research fatigue in the country. Purposeful sampling is widely used in qualitative research for the identification and selection of information-rich cases related to the phenomenon of interest (Proctor et. al. 2010). At the second stage, two wards were randomly selected from the 25 wards in the district to allow for effective coverage of soyabean producers in the wards. The selected wards were Ward 4 and 5, with 24 villages and 30 villages respectively. The village is the smallest administrative unit in Zimbabwe. Cluster sampling was 
then used to select ten (10) villages, five from each ward, based on numerous criteria that included predominant crop production systems within the villages, how representative villages were of the district soyabean production patterns, and their proximity to regional aggregate markets.

The Taro Yamane formula (Yamane, 1967) was used to come up with a sample size of 200 households. A total of 20 households were then chosen from each of the sampled 10 villages. This entailed that 100 households were sampled from Ward 4, while another 100 households were sampled from Ward 5. The sampling frame comprised soyabean smallholder farmers. The researchers obtained the names of all smallholder soyabean farmers, who grew soyabean on areas of less than 10 hectares in the selected villages from the local agronomists. Multiple sampling techniques were used to reduce bias and ensure representative sampling. The aim was to also to select a representative sample to allow for the generalization of findings from the sample to the population (Saunders et al., 2011).

\subsection{Data collection tools}

The study relied on both primary and secondary data. Primary data was largely sourced from the survey, which was itself designed to collect both quantitative and qualitative data. Quantitative data was largely collected using a semi-structured household and intra-household survey questionnaire focusing on smallholder soyabean production and market participation. The collected quantitative data consisted specifically of questionnaire identification, household identification, socio-economic factors, support services, access to input markets, soyabean marketing, soyabean production and its costs, as well as situational, organizational and institutional factors.

Qualitative data was collected using key informant interviews and focus group discussions used to buttress collected quantitative data. All data collection tools, including the semi-structured household questionnaire, were reviewed and pre-tested before use during field data collection to identify problem areas, improve validity, reduce respondent burden, determine whether or not respondents are interpreting questions correctly, and ensure that the order of questions is not influencing the way a respondent answers. Secondary data was composed of published material such as text books, journal articles and e-resources. Secondary data also comprised grey literature which included district-based manuscripts, AGRITEX officer reports and ZIMSTATS bulletins.

\subsection{Data analysis}

The Statistical Package for Social Sciences (SPSS) version 26 was used for entering all quantitative data that was collected. The quantitative data entered in SPSS was later imported to STATA version 15 for analysis, while Microsoft Word 2016 was used for study result documentation. The multinomial logistic regression model, as detailed below, was used for detailed data analysis.

\subsection{Variables and units of measurement}

Table 1 shows the dependent variable, independent variables, their descriptions and units of measurement.

Table 1: Variables and units of measurement

\begin{tabular}{|c|c|c|}
\hline Variable & Description & Units of Measurement \\
\hline \multicolumn{3}{|l|}{ Independent variables } \\
\hline Gender & Gender of household head & $0=$ male $1=$ female $($ binary $)$ \\
\hline Age & Age of household age & Number of years (continuous) \\
\hline Education level & Educational level for household head & $0=$ primary $1=$ secondary (binary) \\
\hline Input price & Price of inputs for soyabean & US dollars (continuous) \\
\hline Access to support services & $\begin{array}{l}\text { Farmer having access to support such as } \\
\text { extension, credit. etc. }\end{array}$ & $1=$ yes $2=$ no (binary) \\
\hline Years in soyabean production & $\begin{array}{l}\text { Number of years the household has } \\
\text { been engaging in soyabean production }\end{array}$ & Number of years (continuous) \\
\hline Access to information & Acquiring information on soyabean & $1=$ yes $2=$ no (binary) \\
\hline Area of soyabean planted & Planted area of soyabean & Hectares (continuous) \\
\hline Household size & $\begin{array}{l}\text { Number of people living per each } \\
\text { household }\end{array}$ & Number (continuous) \\
\hline \multicolumn{3}{|l|}{ Dependent variable } \\
\hline Output market participation & Participation in the output market & $\begin{array}{l}\text { 1=village } \quad \text { market, } \\
3=\text { IETC, } \\
\text { (categorical) }\end{array}$ \\
\hline
\end{tabular}




\subsection{Multinomial Logistic Model}

The regression of multinomial logistics was used to analyze the determinants of output market participation. The model was used since the decision to participate in the output market is a multivariate. The dependent variable is soyabean output market participation with four categories or outcomes which are coded as $0=$ village market, $2=$ GMB, 3= IETC and 4= private buyers. IETC is the reference category. This entails that apart from utilization of village markets, smallholder farmers could also choose to market their crop through the Grain Marketing Board (GMB), IETC - a subsidiary of the Export Trading Group or through other private buyers.

The dependent is discrete variable with $\mathrm{J}$ alternatives $(\mathrm{j}=0,1,2,3)$. The multinomial logistic regression model assumes independence on the market choices since it rejects correlation between the alternatives (Wooldridge, 2006). Greene (2003) stated that multinomial logistic regression model is denoted as:-

$$
p r(y=j)=\frac{\ell^{\beta j x_{i}}}{\ell^{\beta^{0} \chi^{i}}+\ell^{\beta^{j \chi_{i}}}+\ldots+\ell^{\beta^{i \chi^{i}}}}
$$

Given $\operatorname{Prob}(\mathrm{y}=1)$ where $\mathrm{j}=1,2, \mathrm{~J}-1$.

Parameter $\beta$ has two subscripts in the model, $\mathrm{k}$ for distinguishing $\mathrm{x}$ variables, and $\mathrm{j}$ for distinguishing response categories. The subscript $\mathrm{j}$ indicates that there are $\mathrm{J}-1$ sets of $\beta$ estimates. The table (2) shows the a priori expectations for multinomial logistics.

Table 2: A priori expectations for multinomial logistics

\begin{tabular}{|c|c|c|}
\hline Variable & A Priori Expectations & Expected Sign \\
\hline Gender & $\begin{array}{l}\text { Males have more markets to choose in terms of participating } \\
\text { in the output market as compared to females }\end{array}$ & Positive \\
\hline Age & $\begin{array}{l}\text { Old farmers supply more soyabean than young farmers since } \\
\text { old people have more knowledge and their decision in output } \\
\text { participation is high }\end{array}$ & Positive \\
\hline Input price & $\begin{array}{l}\text { Increase in the price of input results in a decrease in output } \\
\text { market participation }\end{array}$ & Negative \\
\hline $\begin{array}{l}\text { Access to } \\
\text { services }\end{array}$ & $\begin{array}{l}\text { Access to support services such as extension, credit, etc. } \\
\text { gives farmers support therefore results in an increase in } \\
\text { soyabean production and market share }\end{array}$ & Positive \\
\hline $\begin{array}{l}\text { Years in } \\
\text { production }\end{array}$ & $\begin{array}{l}\text { The more years in soyabean production the better knowledge } \\
\text { gained and the skill to negotiate reasonable prices and choose } \\
\text { the market that meet their soyabean quality }\end{array}$ & Positive \\
\hline Access to information & $\begin{array}{l}\text { Poor information access results in lack of sound decision } \\
\text { making on output market participation }\end{array}$ & Negative \\
\hline $\begin{array}{l}\text { Area of soyabean } \\
\text { planted }\end{array}$ & $\begin{array}{l}\text { The more land allocated to soyabean the better the production } \\
\text { and benefits from scale of production and bulk delivery to } \\
\text { markets }\end{array}$ & Positive \\
\hline Education level & $\begin{array}{l}\text { The higher the educational level the better understanding to } \\
\text { information leading to output market participation }\end{array}$ & Positive \\
\hline
\end{tabular}

\section{Results and Discussion}

Results of the Multinomial Logistic Regression Model identified determinants for output market participation in Upper Guruve District. See Table 3. 
Table 3: Determinants for output market participation in Upper Guruve District

Output Soyabean market Robust $\quad$ Std. Err.

Coeff.

\section{Village market}

$\begin{array}{lllll}\text { Gender } & 1.301271 & .5663938 & 2.30 & 0.022^{* *} \\ \text { Age } & 1.098703 & .0286234 & 3.84 & 0.000^{* * *} \\ \text { Area in ha } & 1.856071 & 1.047364 & 1.77 & 0.076^{*} \\ \text { Access to support services } & -.6083775 & .6302923 & -0.97 & 0.334 \\ \text { Years in soyabean production } & -.1069033 & .0436714 & -2.45 & 0.014^{* *} \\ \text { Input price } & -.1782826 & .0473673 & -3.76 & 0.000^{* * *} \\ \text { Income } & .0023637 & .0016808 & 1.41 & 0.160 \\ \text { Market information } & 1.649307 & .5184067 & 3.18 & 0.001^{* * *} \\ \text { Constant } & -7.743195 & 1.176924 & -6.58 & 0.000\end{array}$

\section{$G M B$}

Gender
Age
Area in ha
Access to support services
Years in soyabean production
Input price
Income
Market information
Constant

\section{IETC Private Buyers}

Gender

Age

Area in ha

Access to support services

Years in soyabean production

Input price

Income

Market information

Constant

$\begin{array}{ll}-3.74 & 0.000^{* * *} \\ -1.00 & 0.317 \\ 4.44 & 0.000^{* * *} \\ 4.79 & 0.000^{* * *} \\ 2.56 & 0.010^{* * *} \\ 2.00 & 0.045^{* *} \\ 0.02 & 0.984 \\ -0.40 & 0.692 \\ -5.18 & 0.000\end{array}$

(base outcome)

$\begin{array}{llll}.7102946 & .5190564 & 1.37 & 0.171 \\ .0582335 & .022081 & 2.64 & 0.008^{* * *} \\ 3.564154 & 1.062917 & 3.35 & 0.001^{* * *} \\ -1.020979 & .4835781 & -2.11 & 0.035^{* *} \\ -.0532241 & .0357958 & -1.49 & 0.137 \\ -.0848988 & .0498906 & -1.70 & 0.089^{*} \\ -.0019677 & .0011303 & -1.74 & 0.082^{*} \\ 1.099645 & .4847262 & 2.27 & 0.023^{* *} \\ -3.844367 & 1.398947 & -2.75 & 0.006\end{array}$

*Significant at 10\% level; ** Significant at 5\% level; *** Significant at $1 \%$ level;

Number of observations $=200$; Pseudo $\mathrm{R}^{2}=31.20$; Base category is IETC

Source: Survey for the smallholder soyabean farmers in Upper Guruve District 2018

Pseudo $\mathrm{R}^{2}$ imply that about $31.2 \%$ of dependent variable, output market participation was explained by the model.

\subsection{Village market relative to IETC}

Gender is a multinomial logit estimate comparing females to males in the output market of village market relative to IETC given other variables are at constant in the model. Multinomial logit for female farmers to male farmers is 1.3 units higher in selling at village market relative to IETC given all the other market predictor variables in the model are at constant. This implies that woman participate more in the village market since the soyabean crop is mostly grown by women in Upper Guruve District. A similar trend was observed by Alene et al., (2008) in a study conducted in Kenya where women farmers dominated in both soyabean production and output market participation as compared to their male counterparts. This also contrasts with the findings from the study held at Western Oklahoma by Cunningham et al., 2008 which, while acknowledging that gender plays a major role in market participation, revealed that men engage output markets more frequently than women, receiving a lower price as a result.

Age is a multinomial logit estimate for comparing output participation in the village relative to IETC when 
all variables are at constant in the model. The multinomial logit for age is 1.09 units higher in selling in the village market than in the IETC. The older households tend to sell more of their produce in the village market as compared to IETC. This might be explained by a more open attitude to risk and less hesitancy to accept new markets (Ayuya, (2010). The number of years in soyabean production is an estimate for multinomial logit in comparing output participation in the village market relative to IETC given all other variables are constant. Years in soyabean production is 1.07 times lower in selling soyabean in the village market relative to IETC. What this entails is that more experienced farmers weigh the risk behind engaging village markets since they have more experience to make sound decisions regarding marketing channels. Producers with greater areas under soyabean and with more access to market information also engaged the village market more than they would do with IETC, while increases in input prices are likely to reduce engagements with the village market.

\subsection{GMB relative to IETC}

The area under soyabean and access to support services are multinomial logit estimates for comparing output market participation in selling to the Zimbabwean Grain Marketing Board (GMB), a public enterprise, as opposed to the IETC when there are constant variables in the model. The multinomial logit for area under soyabean and access to support services are respectively 4.66 and 3.09 units higher in selling to the GMB than IETC. This is because the more the cropped land the greater the production output and the more producers can engage the GMB which traditionally delays payments to farmers but still regarded as a less risk buyer/off-taker than other alternatives. Soyabean producers with greater output can also afford to market part of the output to private offtakers to generate quick sales and access cash since most pay cash on delivery. The results also entail that soyabean farmers with access to support services such as extension have increased output market participation in GMB since they receive information on current prices and technical assistance from AGRITEX and GMB-linked public agricultural extension agents. According to Alene et al. (2008), access to support services improves the adoption of improved crop varieties which yields more output and increase marketable surplus of the household to meet the yield and output requirements in buyers of last resort such as GMB. Other less significant factors included gender whose result was opposite to earlier findings, years in soyabean production and input prices.

\subsection{Private buyer's comparative to IETC}

Again, the area under soyabean and age are multinomial logit estimates for comparing output participation with private buyers relative to IETC when all variables are at constant in the model. The multinomial logit for area under soyabean and age are 3.5 and 0.06 units higher in selling to private buyers than to IETC. The area under soyabean has sufficiently been discussed above. On the other hand, with regards to age, and according Demeke and Haji (2014) older households tend to market more of their produce to private buyers as compared to other alternatives since they prefer to wait for the private buyers to buy their soyabean as they give instant hard cash. Access to market information has also tended to push soyabean producers more towards private buyers, while increases in input prices will have a reverse effect, which are largely expected results. It was, however, not very clear why greater incomes would drive soyabean producers away from private buyers. This is an area that can be targeted for further research.

\section{Conclusion}

The study analysed the factors that influence participation by smallholder soyabean farmers in output markets in Upper Guruve District, Zimbabwe. The key determinants in output market participation for soyabean included gender, household age, area under soyabean production, years in soyabean production, input price, income, market information and access to support services. The study demonstrates the need for market information dissemination so as to promote and increase soyabean productivity. Government intervention should also focus on providing an enabling environment for improved private sector involvement and gender empowerment since private sector players are limited and women are currently marginalized in soyabean production and market participation. This study is critical for guiding policy-making and the development of strategies to increase soyabean production for the benefit of both smallholder farmers and the rural economy in general

\section{References}

1. Adedoyin, S. F., Torimiro, D. D., Joda, A. O., \& Ogunkoya, A. O. (1998). Adoption of Soybeans Planting, Processing and Utilisation Packages in Ago Iwoye, Proceeding of the $3^{\text {rd }}$ Annual National Conference of the Agricultural Extension Society of Nigeria, 4-6 March

2. Alene, A., Manyong, V., Omanya, G., Mignouna, H., Bokanga, M. and Odhiambo, G. (2008), "Smallholder market participation under transactions costs: Maize supply and fertilizer demand in Kenya", Food policy, Vol. 33, pp. 318-328

3. Ayuya, O. (2010), "Evaluation of willingness to accept and adopt clean development mechanism projects among small scale farmers in Njoro district, Kenya", MSc. Thesis, Department of Agricultural Economics 
and Agribusiness Management, Egerton University, Kenya

4. Barrett, C. B. (2008) 'Smallholder market participation: Concepts and evidence from eastern and southern Africa', Food Policy, pp. 299-317. doi: 10.1016/j.foodpol.2007.10.005.

5. Chikwati Elita and Siam Hind (2018) Govt increases soyabean price | The Herald. Available at: https://www.herald.co.zw/govt-increases-soyabean-price/ (Accessed: 11 November 2018).

6. Cunningham LT, Brown BW, Anderson KB, Tostao E (2008). Gender differences in marketing styles. Agric. Econ. 38(1):1-7

7. Demeke, L.B. and Haji, J. (2014). Econometric analysis of factors affecting market participation of smallholder farming in Central Ethiopia. Journal of Agricultural Economics, Extension and Rural Development: Vol. 2(6): 094-104

8. Duranti, M., Gius, C., (1997). Legume seeds: protein content and nutritional value. Field Crops Research 53, $31-45$

9. Greene, W. (2003) Econometric Analysis.. Fifth Edition ed. New Jersey: Prentice Hall.

10. IFAD (2003) Promoting Market Access for the Rural Poor in Order to Achieve the Millennium Development Goals.

11. Jagwe J, Machethe C, O. E. (2010) 'Transaction costs and smallholder farmers' participation in banana markets in the Great Lakes Region of Burundi, Rwanda and the Democratic Republic of Congo', Afr. J. Agric. Res, 6(1), pp. 1-16.

12. Louw. A., Ndanga, L, Chikazunga, D. and Jagwe, J. (2008). Restructuring food markets in the Southern African region: dynamics in the context of the fresh produce sub-sector: A synthesis of country findings. Department of Agricultural Economics, Extension and Rural Development. Pretoria, South Africa: University of Pretoria.

13. Myaka, F. A., Kirenga, G., Malema, B. (Eds) (2005). Proceedings of the First National Soybean Stakeholders Workshop, 10-11 November 2005, Morogoro, Tanzania.

14. Proctor S, A. T. and L. A. (2010) Sampling. In the Research Process in Nursing, 6th edn. (Gerrish K. and Lacey A., eds), Wiley-Blackwell, Oxford.

15. Saunders, M. N., Saunders, M., Lewis, P., \& Thornhill, A. (2011) 'Research Methods for Business Students'Pearson Education India.

16. Smith, K and W Huyser (1987). World distribution and significance of soybean. In J.R. Wilcox (Ed.) Soybean: improvement, production, and uses. Third Ed. Agron. Monograph. 16. ASA, CSSA, and SSSA, Madison. Pp $1-22$.

17. USAID. (2010). Staple foods value chain analysis country report - Tanzania. Available at http://www.competeafrica.org/Files/Tanzania Staple Foods Value Chain Analysis Study (Accessed 15 January 2019).

18. Wolfgang, V. L, Josephine M, Alan B, S. D. (2016) 'Analysing challenges facing smallholder farmers and conservation agriculture in South Africa: A system dynamics approach', (December). doi: 10.4102/sajems.v19i5.1588.

19. Wooldridge, J. (2006) 'Introductory Econometrics. A Modern Approach', in Introductory Econometrics. A Modern Approach. Third ed. s.l.:South Western College ., pp. 23-45.

20. Yamane, T. (1967) Statistics, An Introductory Analysis 2nd Ed., New York: Harper and Row.

21. Zanello, G., Shankar, B. and Srinivasan, C.S. (2012). Transaction costs, information technologies, and the choice of marketplace amongst farmers in northern Ghana. Paper presented at the $86^{\text {th }}$ Annual Conference of the Agricultural Economics Society, University of Warwick, United Kingdom, 16-18 April, 2012.

22. ZIMSTATS (2013). Annual Report 2013. Zimbabwe National Statistics Agency. 